\title{
ANORTHOSITES AND POLYMETAMORPHISM BETWEEN RAVNS STOR $\varnothing$ AND SUKKERTOPPEN, WEST GREENLAND
}

\author{
Brian F. Windley
}

This report summarises the results of three summers' mapping, 1964-66, forming part of the current 1:500 000 project. The stratigraphy, metamorphism and structure of the previously little known region between latitudes $63^{\circ} 30^{\prime}$ and $64^{\circ}$ have been correlated with those in the southern part of the area mapped by Noe-Nygaard and Ramberg (1961).

It has been possible to follow the main structural and metamorphic development along this section of the pre-Ketilidian fold belt. Much of the original stratigraphy, both igneous and supracrustal, can be followed and by this means the major tectonics have been studied. The structural evolution is characterised both on a major and minor scale by abundant eye-fold interference patterns of folded isoclines, domes, basins and luniform folds.

In the Fiskenæsset region there are stratigraphic anorthosite horizons up to $2 \mathrm{~km}$ wide; nearly all containing abundant chromite layers which have been studied in detail by M. Ghisler (this report). The anorthosites consist predominantly of a basic plagioclase, $\mathrm{An}_{80-96}$, and are commonly layered with hypersthene, diopside, hornblende and chromite. Hypersthene amphibolite (pyribolite) horizons are intercalated with the anorthosites forming a major part of the complex and there are subsidiary pyroxenites, some of which are chromite-layered. The presence of the chromite layering indicates that the anorthosites formed by gravitative differentiation under non-orogenic conditions (Windley, in press).

In Fiskenæsset fjord itself hypersthene-diopside bearing anorthosites and pyribolites are situated in hypersthene gneisses, which contain graphite in places, and are cut by hypersthene pegmatites, whereas to the north and south these rocks occur in hornblende-biotite gneisses containing relics of hypersthene gneiss. Whilst the granulite facies gneisses have been downgraded under amphibolite facies conditions, the anorthosites and pyribolites retain their granulite facies assemblages in the amphibolite facies area as they have lagged behind in retrogression. Both the progressive granulite and retrogressive amphibolite facies metamorphisms were essentially isochemical, thus preserving the original structures of the anorthosite complex in an unmigmatised state. 
Sapphirine-bearing rocks, including that of the type locality at Fiskenæsset, belong to the anorthosite complex and formed by polymetamorphism of an original ultramafic igneous assemblage.

Whereas some amphibolite facies complexes have been derived by downgrading of granulite facies complexes (e.g. Fiskenæsset region, Fiskefjord), others have been formed by progressive metamorphism and so have never been at a higher grade. (e.g. Ravns Stor $\phi$, Godthåbsfjord, Alangua fjord). Whereas the retrogressive amphibolite facies areas rarely contain recognisable metamorphic derivatives of supracrustal rocks, the progressive areas commonly have well-preserved original structures and diagnostic lithologies. For example:

a) East of Ravns Stor $\varnothing$ there is an amphibolite horizon containing well-preserved pillows, agglomerates, amygdules and quartzites in a thermal low where the rocks have not been above greenschist facies. There is also a highly migmatised chromite-free anorthosite horizon made up of two types: a leucocratic anorthosite consisting almost entirely of basic plagioclase, and a gabbroic anorthosite with coarse aggregates of hornblende.

b) In the gneisses of Godthåbsfjord there are recognisable supracrustal lithologies: sillimanite gneisses, sillimanite-graphite mica schists, staurolitegraphite schists, pillow- and agglomerate-bearing amphibolites, meta-quartzites, diopside-skarn para-amphibolites, calc-silicate lenses and garnet-mica schists.

c) In the gneisses of Alangua fjord there are unmigmatised amphibolite horizons containing probable pillows, quartzitic layers, sillimanite gneisses and sillimanite-mica schists.

On the west side of Nordland there are relict horizons of gabbroic and leucocratic anorthosite highly migmatised by hypersthene gneiss. This may suggest that the granulite facies rocks here are a higher grade, equivalent to the amphibolite facies rocks of Godthåbsfjord.

At least three major periods of migmatisation can be distinguished in the Godthåbsford region. The first, which is in association with the formation of the gneisses, has migmatised anorthosite horizons consisting of the leucocratic and gabbroic anorthosites, the second has migmatised a swarm of amphibolite dykes (McGregor, this report) and the third has given rise to the Qorqut granite (McGregor, this report). 


\section{References}

Noe-Nygaard, A. and Ramberg, H. (1961) Geological reconnaissance map of the country between latitudes $69^{\circ} \mathrm{N}$ and $63^{\circ} 45 \mathrm{~N}$, West Greenland Medd. Grфnland, Bd.123, Nr.5.

Windley, B. F.' (in press) On the classification of the West Greenland anorthosites. Geol. Rdsch.

\section{MIGMATIZATION AND DEFORMATION IN AMERALIK, GODTHÅB COMMUNE, WEST GREENLAND, AND THEIR AFFECT ON A SWARMI OF BASIC DYKES}

\section{V.R. McGregor}

Basic dykes $35 \mathrm{~km}$ south of Godthåb were recognized by Berthelsen (1955) as separating two periods of plutonic activity. This swarm has now been traced over the outer $40 \mathrm{~km}$ of Ameralik and north into the southern part of Godthåbsfjord, and may extend over a much larger area. A study of the deformation and migmatization of these dykes has been used to work out the history of the outer part of Ameralik.

The K/Ar published for a pegmatite cutting the Qorqut granite (Larsen, this report) suggests that the youngest plutonic rocks in the Ameralik Godthåbsfjord region were formed at about $1810 \mathrm{~m} . \mathrm{y}$. This is considerably younger than the dates published from the retrograde gneisses of the Ipernat dome to the north and the granulitic rocks of the Fiskenæsset area and supports the idea that there has been a local development of late granitic rocks in the Ameralik - south Godthåbsfjord region.

The geological history of the outer part of Ameralik can be summarized as follows:

(h) Faulting and intrusion of dolerite and lamprophyre dykes.

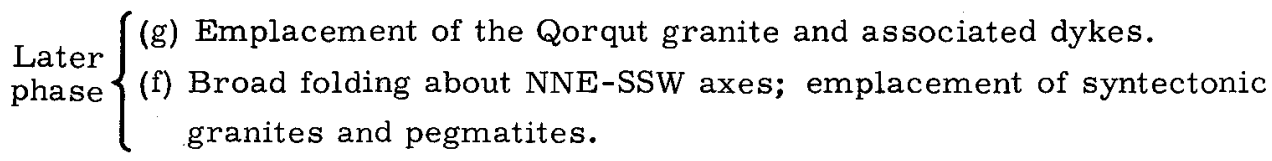

